\section{THE ASTRONOMICAL HISTORY OF ON AND THEBES.}

$\mathrm{I}$ a previous article I have attempted to show that there was a considerable difference of astronomical thought between those, on the one hand, who built pyramids and temples facing true east and west and those, on the other, who built solar temples not oriented to the equinox, but rather, though not exclusively, to the solstice.

It was suggested that although in the matter of simple worship the sun would come before the stars ; in temple worship the conditions would be reversed in consequence of the stable rising and setting places of the latter as compared with those of the sun at different times of the year.

Another suggestion was hazarded that sun templeworship might have been an accidental result of the sunlight entering a temple which had really been built to observe a star; and that such temple sun-worship might possibly have preceded the time at which the solstices and equinoxes, and their importance, had been made out. I think it is possible to show that this really happened, and we owe the demonstration of this important fact to the Egyptian habit of having two associated temples at right angles to each other, because this habit justifies the assumption that at On the single obelisk which now remains not only indicates the certain existence in former times of one temple, but in all probability of two at right angles to each other.

But this is only one point among many to which one may appeal in approaching the study of the question. Another of great importance is brought before us in the masterly essay by M. Virey, entitled "Notices Générales," on the discoveries made at Der el-Bahari by MM. Maspero and Grébaut.

In his account of the confraternity of Amen and of the various attempts made by the Theban priests to acquire political power he refers to the action of Amenhetep IV. (Chu-en-Aten). 1

In the time of Thotmes III. the alliance between the royal and the sacerdotal power was of the closest, and in no time of the world's history have priests been more richly endowed than were then the priests of Amen. Not content, however, with their sacred functions, they aimed at political power so obviously that Thotmes IV. and Amen-hetep III., to check their intentions, favoured the cults and priesthoods of $\mathrm{On}$ and other cities of the north. Amen-hetep IV. went further; he looked for alliances out of Egypt altogether, and entered into diplomatic relations with the princes of Asia, including even the king of Babylon. This brought him and the priests to open warfare. He replied to their anger by prescribing the cult of Amen. The name of Amen was effaced from the monuments, still the priestly party was strong enough to make it unpleasant for the king in Thebes, and to deal them yet another blow, he quitted that city and went to settle at Tell el-Amarna, at the same time reviving an old Heliopolitan cult. He took for divine protection the solar disc Aion, "which was one of the most ancient forms of one of the most ancient gods of Egypt, R $\bar{a}$ of Heliopolis." Now let us say that the time of Amen-hetep IV., according to the received authorities, was about 1450 B.C. The lines of the "Temple of the Sun" at Tell el-Amarna are to be gathered from Lepsius's map, the orientation is $13^{\circ}$ north of west. This gives us a declination of $\mathrm{II}^{\circ}$ north, and the star Spica at its setting would be visible in the temple, and the sunlight at sunset would enter the temple on April I 8 and August 24 of the Gregorian year.

Hence, then, the temple was probably built really to observe the sunset on a special day in the year. In this

1 "Notices des Principaux Monuments Exposés au Musée de Gizeh," p. 260.1893 .

$$
\text { NO. I 240, VOL. } 48]
$$

view how appropriate was the prayer of Aahmes, Chu-enAten's chief official.

"Beautiful is thy setting, thou sun's disk of life, thou Lord of Lords and King of the worlds. When thou unitest thyself with the heaven at thy setting, mortals rejoice before thy countenance and give honour to him who has created them, and pray before him who has formed them, before the glance of thy son who loves thee the King Khu-en-aten. The whole land of Egypt and all peoples repeat all thy names at thy rising, to magnify thy rising in like manner as thy setting."

Still perhaps more beautiful was the prayer of the queen.

"Thou disk of the Sun, thou living God! there is none other beside thee! Thou givest health to the eye through thy beams. Creator of all beings. Thou goest up on the eastern horizon of heaven to dispense life to all which thou hast created; to man, four-footed beasts, birds, and all manner of creeping things on the earth, where they live. Thus they behold thee, and they go to sleep when thou settest.

"Grant to thy son, who loves thee life in truth, to the lord of the land, Khu-en-aten, that he may live united with thee in eternity.

"As for her, his wife, the Queen Nefer-it-Thi, may she live for evermore and eternally by his side, well pleasing to thee ; she admires what thou hast created day by day." I

Still the light of Spica would not enter it axially if the orientation is correct. This would have happened in 2000 B.C., that is 600 years before the time of Amen-hetep IV. This is a point which Egyptologists must discuss ; ${ }^{2}$ it is quite certain that such a pair of temples as those of which Lepsius gives us the plans could not have been completely built in his short reign, and they would not perhaps have been commenced on heretical lines in any previous reign during the I8th dynasty. It must there. fore have been commenced before 1700 B.C., perhaps in the 17th dynasty In any case it was certainly finished by Chu-en-Aten.

But this "temple of the Sun" was not built alone. There was another at right angles to it, and while Spica was seen setting in one, a star near $\gamma$ Draconis was rising in the other.

Remembering then that the temple attributed to Amenhetep IV. pointed to Spica, let us recur for a moment to the temple conditions at Thebes. There, as we have seen, the temple of Mut is associated with one at right angles to it, facing north-west. The amplitudes are $72 \frac{1}{2}^{\circ}$ north of east and $17 \frac{1}{2}^{\circ}$ north of west. I have shown that the temple of Mut would allow $\gamma$ Draconis to be seen along its axis about 3200 B.C. I now state that Spica would be seen along the axis of the rectangular temple at the same time.

We have next to consider what had taken place at Thebes, so far as we can trace it on the orientation hypothesis since 3200 B.C. ; but to understand thoroughly what was done another reference to M. Virey's essay is necessary. One of the chief aims of the confraternity of Amen was to abolish the worship of Set, Sit, or Sutech, that is generically the stars near the north pole, and, as it can be shown, in favour of the southern ones. The temple of Mut was the chief temple at Karnak, in which the cult of the northern stars was carried on.

We can now realise what the Theban priests got Thotmes to do.

In his day the cult of Spica (the solar disc, Aton, Min, Khem), and $\gamma$ Draconis (the Hippopotamus and Lion Isis) was supreme. The little shrine of the Theban Amen was enlarged and built right aross the fairway

1 Translated by Brugsch, “Egypt," p. $22 \mathbf{r}$

2 Since the above was written, Prof. Flinders Petrie has been good enough, in reply to an inquiry, to state his opinion that the temple was entirely buit by Chu-en-Aten. Should this be confirmed, it may have been oriented directly to the sun, on the day named, or more probably built parailel to some former temple, for traces of other temples are shown on Lepsius plan, and I presume Chu-en.Aten is not stupposed to have built all of them. 
of the temple of Mut, so that the worship was as effectively stopped as the worship of Isis was stopped at Pompeii by the town authorities (when it was prohibited by law), bricking up the window through which the star was observed.

Further, the shrine so restored was of such magnificence that the Spica temple, which had hitherto held first rank, became an insignificant chapel in comparison. Nor was this all. In order still to emphasise the supremacy of Amen, a third-rate temple was erected to Ptah.

We may now return to Amen-hetep's doings at Tell el-Amarna. The worship he emphasised there exactly resembled that which had in early times been paramount at Heliopolis. One based on it, but not identical with it, had been in vogue at Thebes from 3200 B.C. to the time of Thotmes, who, as the tool of the confraternity of Amen, intensified the solstitial worship, and did his best to kill that which had been based upon the Heliopolis cult.

The next question we have to consider is whether the researches at Heliopolis bear this surmise out. It is true we have but one poor obelisk, but let us see what we can make of it. As I have shown, the north and south faces bear $13^{\circ}$ north of west- $13^{\circ}$ south of east. Amen-hetep or some one of the preceding kings of Egypt, when reintroducing the old worship at Tell el-Amarna orients the solar temple $13^{\circ}$ north of west according to the data available. Now when we take the difference of latitude between Heliopolis and Tell elAmarna into account we find that the same declination (within half a degree) is obtained from both.

I have elsewhere shown that there is good reason for believing that the original foundation of the temple at On dates from the time when the north member of the system was directed to $a$ Ursæ Majoris. This was somewhat earlier than 5000 B.C.

Bearing in mind the facts obtained with regard to other similar rectangular systems, we are led to inquire whether at that date a temple oriented to declination $I I^{\circ}$ north was directed to any star.

We find that the important star Capella was in question.

Now so far in my references to stars no mention has been made of Capella. It is obvious that the first thing to be done on the orientation hypothesis is to see whether any other temple, and if of known cult so much the better, is found oriented to Capella. There is one such temple; it is the small temple of Ptah, just mentioned as having been erected by Thotmes. (Time of Thotmes III. I600 B.C. Amplitude of temple $\pm 35^{\circ}$ west of north $=$ with hills $3^{\circ}$ high $32 \frac{1}{2}^{\circ}$ north declination; Capella $33^{\circ}$ north declination about I 700 B.C.)

And now it appears there is another. During the year I892 the officers of the Museum of Gizeh, under the direction of M. de Morgan, excavated a temple at Memphis to the north of the hut containing the recumbent statue of Rameses, and during their work they found two magnificent statues of Ptah, "les plus remarquables statues divines qu'on ait encore trouvées en Egypte," 1 and a colossal model in rose granite of the sacred boat of Ptah.

These discoveries have led the officers in question to the conclusion that the building among the ruins of which these priceless treasures have been found is veritably the world-renowned temple of Ptah of Memphis. It may therefore be accepted as such for the purpose of the present inquiry, although it is difficult to reconcile its emplacement in relation to the statues with the accounts given by the Arab historians.

In January, r893, Captain Lyons, R.E., was good enough to accompany me to determine the orientation of

$$
1 \text { New Gizeh Catalogue, p. 6r. }
$$

NO. I 240 , VOL. 48 ] the newly uncovered temple walls. We had already, two years previously, carefully measured the bearings of the statues of Rameses. We found the temple in all probability facing westwards, and not eastwards, this we determined by a seated statue facing westwards; and its orientation, assuming a magnetic variation of $42^{10}$ westto be $123^{\circ}$ north of west and the hills, in front of it, as, suming the village of Mit-Rahineh non-existent, to be $50^{\prime}$ high.

Here, then, we get reproduced almost absolutely the conditions of the obelisk at Heliopolis in a Ptah temple oriented to Capella 5200 B.C.

We are driven then to the conclusion that the star Capella is personified by Ptah, and that as Capella was worshipped setting, Ptah is represented as a mummy. If this be so we must also accept another conclusion. That the temples both at Heliopolis and Memphis were dedicated to Ptah. About 5300 B.C. we seem almost in the time of the divine dynasties, and begin to understand how it is that in the old traditions Ptah precedes Rã and he is called "the father of the beginnings, and the creator of the egg of the Sun and Moon. ${ }^{1}$

What, then, was this worship which had been absent from Thebes, but which had held its own to the north to such an extent that Amen-hetep IV. went back to it so eagerly? It could not have been the worship of Capella as a star alone, for such worship had been provided for by Thotmes III. by building temple G. Nor could it have been the worship of Spica as a star alone, for in that case the precedent of On would not have been appealed to. We are driven to the conclusion that it was the worship of the sun's disc when setting, at the time of the year heralded by these stars, when it had the declination of $10^{\circ}$ north. The dates on which the sun had this declination were, as already stated, about April I 8 and August 24 of our Gregorian year. The former, in Egypt, dominated by the Nile, was about the time of the associated spring and harvest festivals.

So much for the Ptah mummy form of the Sun-God, to which the Theban priests erected no temples. There was still another, the worship of which existed at Thebes, but which they did their best to abolish by the intensification of the worship of Amen-Rā. I refer to the worship carried on in the temple oriented to Spica. This, there can be no doubt, was the worship of Min, Khem in ithyphallic mummy form. This was associated with the harvest home festival on May I. (Amplitude of temple, I $7 \frac{1}{2}$ north of west, declination $15^{\circ}=$ sun's declination on May I.)

It seems, then, that the suggestion that possibly sunworship existed before the solstitial solar worship is amply justified.

Now so far as my inquiries have yet gone, there is not above Thebes, with the single exception of Redesieh, any temple resembling the On-Thebes ones to which I have directed attention as having a high north-east amplitude.

Similarly, with one or two exceptions which may be late, there are no temples facing the south-east below Thebes.

In short, in Lower Egypt the temples are pointed to stars rising near the north point of the horizon or setting west of north. In Upper Egypt we deal chiefly with temples directed to stars rising in the south-east.

Here again we are in presence of as distinct differences in astronomical thought and methods of observation as we found among those who directed temples to the sun at the equinox, as opposed to those who worshipped that luminary at some other time of the year.

Now with regard to the northern stars observed rising in high amplitudes we have found traces of their worship in times so remote that in all probability at On

I Brugsch," Religion and Mytologie," p. rrx. Pierret, "Salle Historique de la galerie Égyptienne" (du Louvre), p r9g. 
and Denderah a Ursæ Majoris was used before it became circumpolar. We deal with 5000 B.C.

Since undoubtedly new temples with nearly similar amplitudes (such as that denoted by $\mathrm{M}$ at Karnak) were built in late times, we find so long a range of time indicated that the utility of the stellar observations from the yearly point of view could scarcely have been in question.

It may be suggested therefore that the observations made in them had to do with the determination of the hours of the night; this seems probable, for in Nubia at the present day time at night is thus determined.

It may be that such stars as Canopus were used by the southern peoples for the same purpose as $a$ Ursæ Majoris first and then $\gamma$ Draconis were used by the northerners. In other words, the question arises whether the extreme north and south stars were not both used as warners of the dawn all the year round.

It is well known that in quite early times means had been found of dividing the day and night into 12 hours. In the day shadows cast by the sun, or sundials, might have been used, but how about the night?

We have seen that the Egyptians chiefly, if not exclusively, observed a heavenly body and the position of other bodies in relation to it, when it was rising or setting, so that it was absolutely essential that the body which they were to observe should rise and set. Everybody knows that as seen in England there are many stars which neither rise nor set. The latitude of London being $51^{\circ}$, the elevation of the pole therefore is $51^{\circ}$.

Hence, any star which lies within that distance from the pole cannot set, but sweeps round without touching the horizon at all. The latitude of Thebes being $25^{\circ}$, the distance from the pole to the horizon is much smaller, and so the number of stars which do not rise and set is much smaller. The stars which do not rise or set are stars near the pole, and therefore stars which move very slowly, and the stars which rise most to the north and most to the south are those bodies which are moving most slowly while they yet rise or set. Can this slow rate of motion have had anything to do with such stars being selected for observation, the brightest star to the north, most slowly moving, the brightest star to the south most slowly moving? 'It is possible that observations of these stars might have been made in such a way that at the beginning of the evening the particular position of $\gamma$ Draconis, for instance, might have been noted with regard to the pole star: and seeing that the Egyptians thoroughly knew the length of the night and of the day in the different portions of the year, they could at once the moment they got the starting point afforded by the position of this star practically use the circle of the stars round the north pole as the dial of a sort of celestial clock. May not this really have been the clock with which they have been credited? However long or short the day, the star which was at first above the pole star, after it had got round so that it was on a level with it, would have gone through a quarter of its revolution.

In low northern latitudes, however, the southern stars would serve better for this purpose, since the circle of northern circumpolar stars would be much restricted. Hence there was a reason in such latitudes for preferring southern stars. With regard both to high north and south stars then, we may in both cases be in presence of observations made to determine the time at night. So that the worship of Set, the determination of the time at night by means of northern stars, might have been little popular with those who at Gebel Barkal and elsewhere in the south had used the southern ones for the same purpose, and this may be one reason why the Theban priests, representing Nubian astronomical culture and methods, were pledged to drive the cult of Sutech out of the land.

Since then the observations of $\gamma$ Draconis might be used to herald the sunrise almost all the year round, and since the modern constellation Draco is the old Hippopotamus we can readily understand Plutarch's statement that "Taurt presides over the birth of the sun," and why Taurt or Maut should be called the Mistress of Darkness. ${ }^{1}$

It does not seem too much to hope that the continuation of such inquiries may ultimately enable us to solve several points connected with early Egyptian history. We read in Brugsch :-2

"According to Greek tradition, the primitive abode of the Egyptian people is to be sought in Ethiopia, and the honour of founding their civilisation should be given to a band of priests from Meroë. Descending the Nile, they are supposed to have settled near the later city of Thebes, and to have established the first state with a theocratic form of government."

"But it is not to Ethiopian priests that the Egyptian Empire owes its origin, its form of government, and its high civilisation; much rather was it the Egyptians themselves that first ascended the river to found in Ethiopia temples, cities, and fortified places, and to diffuse the blessings of a civilised state among the rude darkcoloured population."

... "Strange to say, the whole number of the buildings in stone, as yet known and examined, which were erected on both sides of the river by Egyptian and Ethiopian kings, furnish the incontrovertible proof that the long series of temples, cities, sepulchres, and monuments in general, exhibit a distinct chronological order, of which the starting point is found in the pyramids, at the apex of the Delta."

(To be continued.)

J. NORMAN LOCKYER.

\section{A PERIODIC MERCURY PUMP.}

HAVE designed and constructed the instrument described in the following lines to reduce the labour of working pumps of the Sprengel class. It has proved itself to be so serviceable in our laboratory that I believe a short descripion of it may be useful to those who

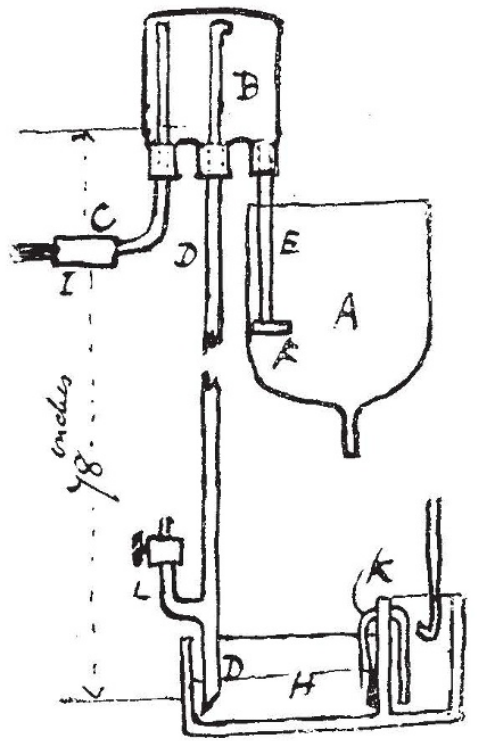

are engaged in work in which the mercurial pump is employed.

A is the cistern of the Sprengel pump (not shown), B is a bottle having three necks: it is furnished with three tubes, $C, D D, E F$; , which has a valve at $I$, is attached

$$
\text { I Rawlinson, i. } 337 . \text { " Egypt under the Pharaohs," ed. } 1891, \text { p. } 3 .
$$

